\title{
Study of the Acute Toxicity of a New Dosage Form of Naloxone Hydrochloride for Intranasal Administration
}

\author{
Authors \\ Eduard A. Bariev, Ivan I. Krasnyuk, Maria N. Anurova, Elena O. Bakhrushina, Valery V. Smirnov, Alexander I. Bardakov, \\ Natalya B. Demina, Ivan I. Krasnyuk Jr.
}

\author{
Affiliation \\ Sechenov First State Medical University, Moscow, Russia \\ Key words \\ pharmaceutics, toxicology, pharmacology, drug research \\ received $\quad 25.03 .2019$ \\ accepted $\quad 16.04 .2019$ \\ Bibliography \\ DOI https://doi.org/10.1055/a-0899-4948 \\ Published online: 16.9.2019 \\ Drug Res 2020; 70: 23-25 \\ (c) Georg Thieme Verlag KG Stuttgart · New York \\ ISSN 2194-9379 \\ Correspondence \\ Elena O. Bakhrushina \\ Sechenov First State Medical University, \\ 8 Trubetskaya building 2, \\ 119991 Moscow, \\ Russia \\ Tel.: + 7/495/6091400 \\ bachrauschenh@mail.ru
}

\begin{abstract}
The experiment was conducted on 10 Wistar rats, male and female, with initial body weight $270-280 \mathrm{~g}$ (males) and 250$260 \mathrm{~g}$ (females). The drug was administered using a spray cap in 10 doses of $0.1 \mathrm{mg}$ at $45 \mathrm{~min}$ intervals. The average cumulative dose of the drug per naloxone hydrochloride was $36.6 \mathrm{mg} /$ $\mathrm{kg}$ for males and $39.4 \mathrm{mg} / \mathrm{kg}$ for females. The animals were monitored for 2 weeks after the exposure and then euthanized by a gentle decapitation.

We noticed that after each drug administration the animals showed a decrease in motor activity. During the observation period there were no animal deaths or signs of abnormalities in their general state or behavior. Beginning on day 7 a significant increase in body weight of the animals was noted in comparison with the initial data. The relative mass of the internal organs of the treated rats remained within the physiological norm.

We conclude that naloxone hydrochloride after an intranasal administration at $36.6 \mathrm{mg} / \mathrm{kg}$ for males and $39.4 \mathrm{mg} / \mathrm{kg}$ for females does not cause death of animals and or have a toxic effect on their general state, does not change their protein metabolism characteristics or the appearance of the internal organs and their mass.
\end{abstract}

\section{Introduction}

In the beginning of the 1970 s several drugs having some properties of opiate antagonists were used. These drugs allow quickly and effectively relieve the severe syndrome of abstinence accompanying the addiction. Naloxone proved to be the purest antagonist, and could be used as an antidote for the treatment of opiate overdoses (including the respiratory depression caused by large doses of heroin). In the world practice, naloxone has been established a drug used in emergency medicine for the treatment of opiate overdoses $[1,2]$.

Naloxone is a competitive antagonist of opioid receptors. It blocks predominantly $\mu$ and $x$ receptors, and to a lesser extent affects other opioid receptors. Naloxone easily overcomes the blood-brain barrier, blocking both peripheral and central opioid receptors [1,3].

Naloxone is a highly active, but short-acting antagonist (after an intravenous injection of $0.4 \mathrm{mg}$ the effect lasts from 20-40 min). Naloxone is poorly absorbed in the gastrointestinal tract and is rapidly metabolized in the body $[1,3]$.
Currently, naloxone hydrochloride monopreparations on the Russian pharmaceutical market are represented by 7 names in the form of solution for injection, and only two of those are of domestic production [4]. However, with the need for rapid provision of first aid for acute intoxication with opioids, parenteral administration, technically complex and not feasible in the absence of qualified medical personnel, is notably inferior to the intranasal administration of naloxone. This route of administration is technically simple and devoid of risks arising from the parenteral administration, and is also capable of having a systemic effect [5]. In this regard, the development of the composition and production technology of naloxone nasal dosage form is deemed promising.

The purpose of the present work was to study acute toxicity of the naloxone hydrochloride drug form intended for intranasal use. 
- Table 1 Toxicity of intranasal naloxone.

\begin{tabular}{|l|l|l|l|l|}
\hline Preparation & Sex of the animals & Number of animals & Dose, $\mathbf{~ m g} / \mathbf{k g}$ (of naloxone hydrochloride) & Lethality, \% \\
\hline \multirow{2}{*}{ Naloxone spray } & Males & 5 & 36.6 & 0 \\
\cline { 2 - 5 } & Females & 5 & 39.4 & 0 \\
\hline
\end{tabular}

- Table 2 Body mass dynamics of rats following an acute exposure to the drug.

\begin{tabular}{|l|l|l|l|}
\hline \multirow{2}{*}{ Preparation } & \multirow{2}{*}{$\begin{array}{l}\text { Time of measure- } \\
\text { ment, days }\end{array}$} & \multicolumn{2}{|l|}{ Body mass, $\mathbf{g}$} \\
\cline { 3 - 4 } & & males & females \\
\hline \multirow{3}{*}{$\begin{array}{l}\text { Naloxone } \\
\text { spray }\end{array}$} & 0 & $273.0 \pm 2.00$ & $254.0 \pm 1.87$ \\
\cline { 2 - 4 } & 3 & $285.0 \pm 5.00$ & $258.0 \pm 1.22$ \\
\cline { 2 - 4 } & 7 & $283.0 \pm 3.39^{1}$ & $260.0 \pm 1.58^{1}$ \\
\cline { 2 - 4 } & 14 & $309.0 \pm 4.85^{1}$ & $262.0 \pm 2.55^{1}$ \\
\hline
\end{tabular}

Note: ${ }^{1} \mathrm{p} \leq 0.05$ relative to the initial values.

- Table 3 Biochemical parameters of rat serum following acute exposure to naloxone.

\begin{tabular}{|l|c|c|c|c|}
\hline \multirow{2}{*}{ Parameter } & \multicolumn{2}{|c|}{ Control } & \multicolumn{2}{c|}{ Naloxone spray } \\
\cline { 2 - 5 } & males & females & males & females \\
\hline $\begin{array}{l}\text { Total } \\
\text { protein, g/l }\end{array}$ & $71.79 \pm 3.30$ & $75.58 \pm 3.88$ & $72.47 \pm 2.68$ & $79.63 \pm 4.39$ \\
\hline Albumin, g/l & $31.78 \pm 1.83$ & $30.79 \pm 1.67$ & $32.65 \pm 1.99$ & $31.15 \pm 2.40$ \\
\hline $\begin{array}{l}\text { Thymol test, } \\
\text { units }\end{array}$ & $1.53 \pm 0.33$ & $1.13 \pm 0.18$ & $1.63 \pm 0.44$ & $1.28 \pm 0.33$ \\
\hline
\end{tabular}

- Table 4 Internal organs mass coefficients following acute exposure to naloxone.

\begin{tabular}{|l|c|c|}
\hline \multirow{2}{*}{ Organs } & Mass coefficients \\
\cline { 2 - 3 } & Males & Females \\
\hline Heart & $0.36 \pm 0.02$ & $0.35 \pm 0.02$ \\
\hline Lungs & $0.73 \pm 0.04$ & $0.85 \pm 0.05$ \\
\hline Liver & $3.27 \pm 0.11$ & $3.28 \pm 0.18$ \\
\hline Adrenal glands & $0.023 \pm 0.001$ & $0.037 \pm 0.001$ \\
\hline Spleen & $0.35 \pm 0.01$ & $0.39 \pm 0.05$ \\
\hline Left kidney & $0.34 \pm 0.01$ & $0.37 \pm 0.02$ \\
\hline Right kidney & $0.35 \pm 0.01$ & $0.37 \pm 0.02$ \\
\hline Left testis & $0.57 \pm 0.02$ & - \\
\hline Right testis & $0.57 \pm 0.02$ & - \\
\hline Thymus & $0.13 \pm 0.02$ & $0.13 \pm 0.01$ \\
\hline
\end{tabular}

\section{Materials and Methods}

The object of the study was a naloxone nasal spray form of the following composition (in $1 \mathrm{~g}$ ): naloxone hydrochloride $10 \mathrm{mg}$ and auxiliary substances (propylene glycol, polyethylene glycol 400 , poloxamer 407 , citric acid monohydrate, purified water); the composition was developed in a previous study [6].

All experiments with animals were carried out in agreement with the European Convention for the Protection of Vertebrate Animals used for Experimental and other Scientific Purposes (ETS No. 123). Wistar rats of both sexes with an initial body weight of $270-280 \mathrm{~g}$ (males) and 250-260 g (females) were used. The experimental groups of animals consisted of 5 males and 5 females. A total of 10 rats were used in the experiment.

The animals were purchased from the Stolbovaya nursery of laboratory animals (Russia). During the quarantine and experiment the animals were kept in a vivarium at an air temperature of $18-20^{\circ}$ C, relative humidity of 50-60\%, the natural day-night light regime, in standard plastic cages, and on a standard diet $[7,8]$.

Nasal administration of naloxone was performed fractionally (10 times of $1.0 \mathrm{mg}$ per naloxone hydrochloride with an interval of 45 min between administrations) using a dispensing spray nozzle. The total dose of the drug for naloxone hydrochloride averaged $36.6 \mathrm{mg} / \mathrm{kg}$ for males and $39.4 \mathrm{mg} / \mathrm{kg}$ for females.

Criteria for judging the toxicity of the drug were the clinical picture of intoxication, survival rate of animals, and the dynamics of their body weight (baseline data, 3, 7, 14 days). Evaluation of the effect of the drug on the functional state of the liver was carried out at the end of the experiment on a number of biochemical parameters of the blood. The content of total protein in the blood was determined by the biuret test, albumin assayed by the reaction with bromocresol green, and the thymol test by sample sedimentation method.

Observation of the animals was carried out for 2 weeks. On the $14^{\text {th }}$ day after the exposure the rats were sacrificed by gentle decapitation. During autopsy according to Roe, a macroscopic observation of the internal organs was done and their relative mass was determined.

All the experimental data were processed by the variation statistics method (the adopted significance level was $p \leq 0.05$ ). The computation of statistical significance in the case of nominal variables was carried out using one-way analysis of variance and variance analysis for experiments with repeated measurement. The hypothesis of equality of two averages was tested using Student's t-test for coupled samples $[7,8]$.

\section{Results and Discussion}

We found that after each injection the animals showed a decrease in motor activity which lasted 5-10 min, and then the animals began to move around the cage, wash themselves, drink water and eat food. Subsequently, the condition and behavior of the rats did not differ from the state and behavior of intact animals.

Animal deaths or abnormalities in their general condition or behavior during the observation period were not noted ( $\vee$ Table $\mathbf{1}$ ).

The effect of naloxone on the body mass dynamics is presented in $>$ Table 2 . We found that beginning from day 7 after the acute exposure there was a significant increase in the weight of animals compared to their initial weight.

Biochemical studies ( $\triangleright$ Table 3 ) indicate that at the doses tested naloxone did not affect the functional state of the liver: total protein, albumin or the thymol test of the serum were similar to those of intact animals. 
A pathology-morphological study performed 14 days after application of the drug at doses of $36.6 \mathrm{mg} / \mathrm{kg}$ for males and $39.4 \mathrm{mg} /$ $\mathrm{kg}$ for females (by naloxone hydrochloride) included autopsy and macroscopic examination of the internal organs. After euthanasia, animals were carefully examined for visible pathological signs. According to the autopsy, there were no abnormalities. Wool was shiny and neat, lymph nodes were not enlarged. Visible mucous membranes were shiny, pale pink, and smooth. All macroscopically examined organs (heart, lungs, thymus, stomach, liver, kidneys, adrenal glands, pancreas, spleen, genital glands) had the usual sizes, color and consistency. The relative mass of the internal organs of the rats received the drug $(\triangleright$ Table 1,4$)$ remained within the limits of the physiological norm [9].

\section{Conclusions}

Based on the acute toxicity study of naloxone nasal spray, we may conclude that the drug at doses of $36.6 \mathrm{mg} / \mathrm{kg}$ for males and $39.4 \mathrm{mg} / \mathrm{kg}$ for females (per naloxone hydrochloride) does not cause animal death, does not have a toxic effect on the general condition, behavior, food and water intake, or body weight of rats; does not affect protein metabolism parameters: the content of total protein, albumin and the thymol test in the sera. There were no visible changes in the internal organs of the rats and their absolute and relative masses were not affected.

\section{Funding}

This research did not receive any specific grant from funding agencies in the public, commercial, or not-for-profit sectors.

\section{Conflict of interest}

The authors of this study do not have any conflict of interests to declare

\section{References}

[1] Kursov SV, Skoroplet SN. Acute poisoning with opioids. Meditsina Neotlozhnykh Sostoyaniy 2016; 2: 48-51. (In Russian)

[2] Bariev EA, Lyapunov NA, Bardakov Al. Validation of the need to develop an intranasal medicinal form for naloxone to treat opioid overdose. Electronic scientific and educational edition Zdoroviye I Obrazovaniye v XXI veke 2017; 19: 9-10. (In Russian)

[3] Mashkovsky MD. Medical products. 17-th edition, Moscow, Novaya Volna Publishers; 2017. (In Russian)

[4] Russian State Registry of medical products, URL: http://grls. rosminzdrav.ru/grls.aspx?s = naloxone (as of 17.03.2018)

[5] Ray B, O’Donnell D, Kahre K. Police officer attitudes towards intranasal naloxone training. Drug Alcohol Depend 2015; 1: 107-110. doi:10.1016/j.drugalcdep.2014

[6] Bariev EA, Bubelo VD, Lyapunov NA. Pharmaceutical development of the domestic drug "Naloxone Nasal Spray" for the provision of emergency medical care as an antidote for acute opioid poisoning (overdose). Uspekhi v Khimii i Khimicheskoi Technologii 2015; 10: 113-114. (In Russian)

[7] Mironov AN, Bunatyan ND. A manual for conducting pre-clinical study of medicinal products. Part 1. Moscow, Grif I K Publishers; 2012: 944 pages. (In Russian)

[8] Arzamastsev EV, et al. Methodological guidelines for the study of the general toxic effects of pharmacological substances Guidelines for the experimental (preclinical) study of new pharmacological substances. Khabriev RU. ed $2^{\text {nd }}$ edition Meditsina Publishers; 2005. (In Russian)

[9] Reference Book: Physiological, biochemical and biometric normal parameters of laboratory animals. Makarov VG, Makarova MN. eds. Saint -Petersburg, LEMA Publishers; 2013. (In Russian) 